\title{
Why Publish in Forensic Science?
}

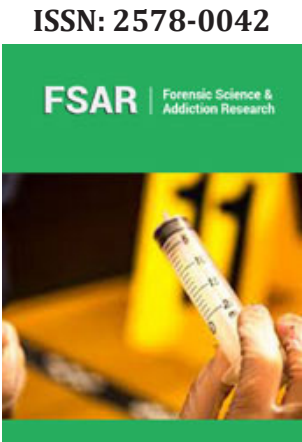

*Corresponding author: Joanna de Ângelis Cavalcante Brasil, Department of Dentistry, Brazil

Submission: 眥 May 07, 2019

Published: 想 May 30, 2019

Volume 4 - Issue 5

How to cite this article: Michael Tkach $\mathrm{J}^{*}$, Considerations for the Clinical Use of Evidence-Based Practice Approaches for Co-Occurring Disorders. Forensic Sci Add Res. 4(5). FSAR.000601.2019. DOI: 10.31031/FSAR.2019.04.000601

Copyright@ Joanna de Ângelis Cavalcante Brasil, This article is distributed under the terms of the Creative Commons Attribution 4.0 International License, which permits unrestricted use and redistribution provided that the original author and source are credited.

\author{
Joanna de Ângelis Cavalcante Brasil* and Tacylla Wanny Barreto Menezes \\ Department of Dentistry, Brazil
}

\begin{abstract}
Publishing is a requirement for any professional who desires reciprocity with the field of science. The production of knowledge are activities inherent to the professional exercise. Forensic science is a broad discipline that encompasses a set of scientific and technical knowledge to answer questions regarding legal, criminal and civil cases. This article aims to give an opinion about the importance of publications in the area of forensic science.
\end{abstract}

\section{Introduction}

The principle of scientific research is the dissemination of knowledge, allowing research results to become accessible and durable to other researchers. The advance in the established theories or the proposition of new theories that occur through the analysis, synthesis and integration of scientific knowledge currently accepted [1].

Forensic Science is an interdisciplinary area comprised of all scientific and technical knowledge that supports civil and criminal justice investigations. Forensic Science and Criminal Investigation, through the development of cross-cutting themes, constitutes a proposal to assist in the construction of a more systemic and contextualized knowledge [2].

\section{Publications in The Forensic Area}

The extraordinary scientific innovations and advances in forensic science have allowed it to become a highly developed science involving a number of disciplines and a number of specialized forensic scientists, providing support for investigations into civil and criminal justice, and also contributing to the advancement of research discussions. Scientific knowledge to exist must be produced. The mere reproduction of knowledge does not bring new advances. Scientific evolution is necessary, shapes the researcher's spirit and promotes changes in the ethical and moral behavior of the citizen.

Publishing in the forensic area conveys knowledge and contributes in some way so that other researchers and other scientists can perfect and reach new discoveries. It is only with studies, research and research that this can be done. Publications in serious and indexed scientific journals in one or more of the major databases make discoveries accessible on a long-term basis. They are fundamental aspects in the systematization of this task in order to provide that more professionals dedicate themselves to it with efficiency.

\section{Conclusion}

The diversity of themes, all of relevance in the forensic sciences, shows the responsibility of the professionals themselves when they engage not only in the daily work, but mainly in providing research, often with personal resources, disseminating the knowledge to the society in which it is inserted. It is salutary this commitment and this personal and nontransferable pleasure in perpetuating scientific knowledge.

\section{References}

1. Mattos (2009) Publish what? Revista Brasil Bot 32(3): 621-623.

2. Chemello E (2006) Forensic science: fingerprints, Virtual Chemistry, Oxford Chemistry, University of Oxford, England, UK, p.1-11.

For possible submissions Click below: 